\title{
Microcystis genotype succession in relation to microcystin concentrations in freshwater lakes
}

\author{
W. Edwin A. Kardinaal ${ }^{1,3, *}$, Ingmar Janse ${ }^{2,4, *}$, Miranda Kamst-van Agterveld $^{2}$, \\ Marion Meima ${ }^{2}$, Josje Snoek ${ }^{1}$, Luuc R. Mur ${ }^{1}$, Jef Huisman ${ }^{1}$, Gabriel Zwart ${ }^{1,2,5}$, \\ Petra M. Visser ${ }^{1, * *}$ \\ ${ }^{1}$ Aquatic Microbiology, Institute for Biodiversity and Ecosystem Dynamics, University of Amsterdam, \\ Nieuwe Achtergracht 127, 1018 WS, Amsterdam, The Netherlands \\ ${ }^{2}$ Department of Microbial Wetland Ecology, Netherlands Institute of Ecology (NIOO-KNAW), Centre for Limnology, \\ Rijksstraatweg 6, 3631 AC Nieuwersluis, The Netherlands \\ ${ }^{3}$ Present address: DHV consultancy, PO Box 1132, 3800 BC Amersfoort, The Netherlands \\ ${ }^{4}$ Present address: National Institute for Public Health and the Environment, PO Box 1, 3720 BA Bilthoven, The Netherlands \\ ${ }^{5}$ Present address: Waterboard Peel en Maasvallei, PO Box 3390, 5902 RJ Venlo, The Netherlands
}

\begin{abstract}
Potentially toxic Cyanobacteria, like Microcystis, form a serious threat in recreational waters and drinking-water reservoirs. We monitored the population dynamics of toxic and non-toxic Microcystis strains using rRNA of the internal transcribed spacer region in combination with DGGE to determine whether there is a seasonal succession of toxic and non-toxic Microcystis genotypes in freshwater lakes and, if so, whether this succession can explain seasonal dynamics of the toxin microcystin. We studied 3 lakes in The Netherlands, all dominated by Microcystis during summer. Coexistence of several genotypes was observed in all lakes. The seasonal succession in a deep, stratified lake started with a population consisting of several toxic genotypes at the onset of the bloom, which changed into a population dominated by non-toxic genotypes at the end of the bloom. In this lake, the genotype succession clearly accounted for the observed microcystin dynamics. In 2 unstratified lakes, we also observed a seasonal replacement of Microcystis genotypes; however, the relation between genotype succession and microcystin dynamics was less conspicuous, since toxic strains dominated throughout the bloom period. A seasonal succession of different Microcystis genotypes might often be a key mechanism determining microcystin concentrations in Microcystisdominated lakes. Therefore, factors driving the succession of toxic and non-toxic genotypes deserve further study.
\end{abstract}

KEY WORDS: Harmful cyanobacteria - Microcystis • Microcystins · Genotypes · Succession · ITS · DGGE

Resale or republication not permitted without written consent of the publisher

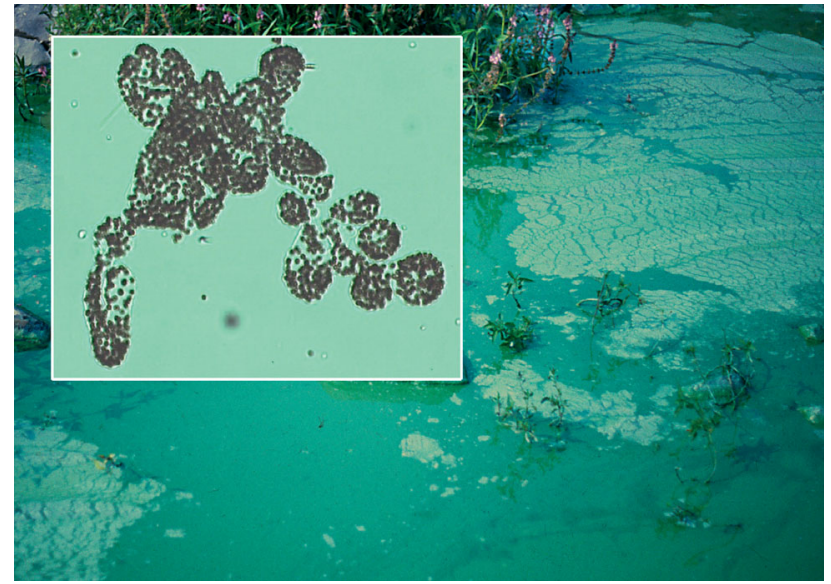

Potentially toxic scum of Microcystis in a freshwater lake; inset: Microcystis colony.

Photos: Josje Snoek (inset) and Petra M. Visser

\section{INTRODUCTION}

Massive blooms of Cyanobacteria in many freshwaters worldwide limit the utilization of recreational waters and drinking water basins due to decreased clarity, bad odor and, in cases of rapid degradation of the bloom, anoxia in the water column. In addition, several Cyanobacteria produce a range of toxins of which the hepatotoxic microcystins are most intensively studied. In many countries, microcystin concentrations have been reported to exceed guideline levels in freshwater lakes and thus pose a serious threat to 
public health and ecosystem functioning (Chorus et al. 2001, Codd et al. 2005). In these lakes, water managers have to take measures to control the microcystin production of harmful Cyanobacteria (Visser et al. 1996, 2005, Chorus \& Bartram 1999, Verspagen et al. 2006a). A better understanding of the microcystin dynamics in recreational waters and drinking water reservoirs will help to improve the water quality in these water bodies.

Microcystins are mainly produced by species of the genera Anabaena, Microcystis and Planktothrix. Since microcystins are mainly found intracellularly, microcystin dynamics are directly related to the population dynamics of the toxin-producing cells (Jähnichen et al. 2001, Kardinaal \& Visser 2005). Biovolumes of potentially toxic Cyanobacteria have been reported to correlate with microcystin dynamics rather well, yet never completely (Fastner et al. 2001, Jähnichen et al. 2001, Wiedner et al. 2002). A profound effect on microcystin dynamics can be expected from changes in the relative abundances of toxic and non-toxic strains (Chorus et al. 2001, Kardinaal et al. 2007). Moreover, successive replacements of toxic strains with different microcystin contents (Rohrlack et al. 2001, Carrillo et al. 2003, Welker et al. 2004) may further contribute to the complexity of microcystin dynamics in lakes. To study the presence of toxic and non-toxic strains, morphological identification has a limited value for 2 reasons: (1) there are uncertainties in the morphological classification of Microcystis species; and (2) within a particular morphotype, some strains can be toxic while others are not (Fastner et al. 2001, Via-Ordorika et al. 2004). Studies focusing on the abundances of Microcystis morphotypes could not identify clear relationships between morphotypes and microcystin dynamics (Watanabe et al. 1992, Jähnichen et al. 2001).

Whether or not a genotype can produce microcystins depends on the presence of intact genes from the microcystin synthetase gene complex (Dittmann et al. 1997, Tillett et al. 2000, Kurmayer et al. 2002). Part of the gene complex, тсуB (Kurmayer \& Kutzenberger 2003) or mcyE (Vaitomaa et al. 2003), has been used to study the relative abundance of microcystin-producing Microcystis cells in the total cyanobacterial community by means of real-time polymerase chain reaction (PCR) (Rinta-Kanto et al. 2005, Ouellette et al. 2006). In these studies, the abundance of toxic Microcystis cells did not show much seasonal variation (Kurmayer \& Kutzenberger 2003), or the abundance of Microcystis cells was overestimated (Vaitomaa et al. 2003). Although the microcystin-producing part of the cyanobacterial community is clearly identified by targeting the mcy genes, the underlying diversity of microcystinproducing strains is not elucidated.
In recent studies, we used PCR and denaturing gradient gel electrophoresis (DGGE) on the rRNA of the internal transcribed spacer (ITS) region to study cyanobacterial diversity, with emphasis on genotypes of the genus Microcystis. This method has a high resolution, differentiates below species level, and proved useful in studies of the diversity of cyanobacterial communities (Janse et al. 2003, Zwart et al. 2005). Based on this method, 107 Microcystis colonies, originating from several lakes throughout Europe, were screened for microcystin content by matrix assisted laser desorption/ionization time-of-flight mass spectrometry (MALDI-TOF), the presence of mcy genes, and their rRNA-ITS gene sequences (Janse et al. 2004). The screening rendered 59 different rRNA-ITS classes based upon the positions in the gels. The classification was confirmed through sequence analyses of the ITS fragments. Microcystin-producing and non-producing colonies were separated into different rRNA-ITS classes (Janse et al. 2004).

In the present study, we applied this rRNA-ITS classification to study 3 Dutch lakes in which Microcystis was a dominant component of the phytoplankton in the summer months. The main goal was to investigate whether a seasonal succession of Microcystis genotypes could be observed in these lakes, and whether this succession could explain part of the variation in microcystin concentrations in the lakes. In each lake, we monitored microcystin concentrations and biovolumes of the genus Microcystis and, when abundant, the genus Planktothrix. In addition, we analyzed Microcystis genotype succession using DGGE and evaluated this succession in relation to microcystin levels.

\section{MATERIALS AND METHODS}

Study area and sampling. The 3 lakes studied are all hypertrophic, situated in the western part of The Netherlands and are intensively used for recreational purposes. Lake 't Joppe is part of a large naturally formed lake system called the Kagerplassen, near the city of Leiden. The maximum depth is $42 \mathrm{~m}$ and the average depth is $13 \mathrm{~m}$, with a surface area of $0.9 \mathrm{~km}^{2}$. The lake stratifies during the summer months. Lake Volkerak, a former estuary of the rivers Meuse and Waal about $20 \mathrm{~km}$ south of Rotterdam, was dammed in 1987 as part of the Delta works (Verspagen et al. 2006a). The surface area of this lake is $46 \mathrm{~km}^{2}$, with an average depth of $5 \mathrm{~m}$ and a maximum depth of $22 \mathrm{~m}$. The lake is completely mixed throughout the year. Lake Kinselmeer, located just north of Amsterdam, was formed through flooding by the former Zuider Sea after a dike burst in the year 1825. The average depth of the lake is $2 \mathrm{~m}$ and the maximum depth is $4 \mathrm{~m}$, with 
a surface area of $1.5 \mathrm{~km}^{2}$. The lake is well mixed throughout the year.

In 2001, all 3 lakes were sampled twice a month from April to October and once a month during the rest of the year. Water samples were collected in the middle of the lakes at $0.5 \mathrm{~m}$ below the surface.

Biovolumes. Water samples, concentrated by sedimentation, were preserved with Lugol's iodine (1:100) directly after sampling and stored at $4^{\circ} \mathrm{C}$. The cell dimensions of the cyanobacterial phytoplankton were measured and the number of cells was counted by inverted light microscopy, using a Sedgewick-Rafter counting chamber (Pyser-SGI). In water samples that contained a high number of Microcystis colonies, the colonies were disintegrated into separate cells by filtering $20 \mathrm{ml}$ of fixed sample onto a $45 \mathrm{~mm}$ diameter, $0.45 \mu \mathrm{m}$ pore size HA membrane filter (Millipore). The filter was transferred to an Erlenmeyer flask and $20 \mathrm{ml}$ $0.01 \mathrm{M} \mathrm{KOH}$ was added. The filters were incubated for $30 \mathrm{~min}$ at $80^{\circ} \mathrm{C}$ and subsequently transferred into a test tube, vortexed for $60 \mathrm{~s}$ and single Microcystis cells were counted. To calculate the microcystin concentration per biovolume (hereafter referred to as microcystin content) in Lake 't Joppe and Lake Volkerak, we used the biovolumes of Microcystis, since Microcystis was the only microcystin-producing genus that we found in these 2 lakes. In Lake Kinselmeer, we found 2 microcystin-producing genera, Microcystis and Planktothrix, and therefore we measured the biovolumes of both.

Microcystin extraction and analysis by HPLC. Water samples were filtered in triplicate over glass microfiber filters (GF/C, $25 \mathrm{~mm}$ diameter, Whatman). Filters were stored at $-20^{\circ} \mathrm{C}$ until further processing. The filters containing cells were lyophilized and subsequently $1.5 \mathrm{ml} 75 \%$ (vol/vol) aqueous methanol was added for extraction of the microcystins according to the method of Fastner et al. (1998) with the modifications described by Wiedner et al. (2003). Microcystins were analyzed by reverse phase HPLC with diode array detection (KONTRON instruments). Different microcystin variants and other oligopeptides were separated on a LichroCart 250-4; Lichrosphere 100 RP-18 (5 $\mu \mathrm{m})$ (Merck), using a gradient of 30 to $70 \%$ (vol/vol) aqueous acetonitrile (with $0.05 \%$ vol/vol trifluoroacetic acid) at a flow of $1 \mathrm{ml} \mathrm{min} \mathrm{mi}^{-1}$ (Lawton et al. 1994). Microcystins were identified using their typical UV spectra, measured with the diode array detection system (Lawton et al. 1994). Microcystin concentrations were subsequently quantified using the peak area of the HPLC chromatograms, calibrated with an external microcystin-LR standard. Microcystin concentrations were expressed as microcystin-LR equivalents, thus summing all detected microcystin variants. Most of the different microcystin variants of Lake Kinselmeer could be assigned to either Planktotrix or Microcystis on the basis of the HPLC chromatograms and UV spectra of the microcystin variants produced by isolates from this lake; thus, we could distinguish between Microcystisand Planktothrix-specific microcystin concentrations in Lake Kinselmeer.

DNA isolation, PCR amplification and DGGE profiling. Within $4 \mathrm{~h}$ after sampling, water was filtered over a $25 \mathrm{~mm}$ diameter, $0.2 \mu \mathrm{m}$ pore size mixed esters filter (ME 24, Schleicher \& Schuell). DNA from filters containing field samples was isolated as described earlier (Zwart et al. 1998). The primer sequence for amplification of the rRNA-ITSc region is described in Janse et al. (2003). PCR amplification was performed in an MBS $0.5 \mathrm{~S}$ thermocycler (Thermo-Hybaid) in a $50 \mu$ reaction mixture containing approximately $100 \mathrm{ng}$ of DNA, $20 \mu \mathrm{g}$ of bovine serum albumin (New England Biolabs), $10 \mathrm{mM}$ Tris- $\mathrm{HCl}$ (pH 8.3), $50 \mathrm{mM} \mathrm{KCl}, 0.01 \%$ (wt/vol) of gelatin, $200 \mu \mathrm{M}$ (each) deoxynucleotide, $1.5 \mathrm{mM} \mathrm{MgCl2}, 2.5 \mathrm{U}$ of Taq DNA polymerase (Boehringer Mannheim), and $0.5 \mu \mathrm{M}$ primer. After preincubation at $94^{\circ} \mathrm{C}$ for $5 \mathrm{~min}$, a total of 30 cycles were performed, starting at $94^{\circ} \mathrm{C}$ for $1 \mathrm{~min}$, and followed by cycles with a specified annealing temperature $\left(T_{\mathrm{a}}\right)$ for $1 \mathrm{~min}$. In the first 20 cycles, $T_{\mathrm{a}}$ decreased by $1^{\circ} \mathrm{C}$ after every second cycle, from $62^{\circ} \mathrm{C}$ in the first cycle to $52^{\circ} \mathrm{C}$ in the twentieth. This touch-down procedure was followed to reduce non-specific annealing of the primers. In the last 10 cycles, $T_{a}$ was $52^{\circ} \mathrm{C}$. The temperature cycling was concluded with a final step of $30 \mathrm{~min}$ at $72^{\circ} \mathrm{C}$.

PCR products were separated on a $1.5 \mathrm{~mm}$ thick, vertical DGGE gel containing $8 \%$ (wt/vol) polyacrylamide (37.5:1 acrylamide: bisacrylamide) and a linear gradient of the denaturants urea and formamide (Janse et al. 2003). The gels were run at $75 \mathrm{~V}$ for $16 \mathrm{~h}$ under continuous circulation of $0.5 \times \mathrm{TAE}$ buffer of $60^{\circ} \mathrm{C}$. After staining of the gel in water containing $0.5 \mu \mathrm{g} \mathrm{ml} \mathrm{m}^{-1}$ ethidium bromide, an image of the gel was recorded with a CCD camera system (Imago, B\&L Systems).

Sequencing of DNA from DGGE bands and DGGE gel picture analysis. For sequence purposes, target bands were excised from the DGGE gel and processed in accordance with Janse et al. (2003). PCR products were purified and both DNA strands were sequenced. Contigs from forward and reverse sequences were constructed using the program Sequencher version 4.0.5 (Gene Codes) and similarity with sequences deposited in GenBank/EMBL/DDBJ was checked using the program BLAST (Altschul et al. 1997; see www.ncbi.nlm.nih.gov/BLAST/). DGGE gel pictures were analyzed using the Phoretics-1D package (Nonlinear Dynamics). Lanes were created manually with a fixed width, and each lane represented 1 sampling day. Peaks smaller than $1 \%$ of the maximum peak 
were discarded. The vertical position of the bands was expressed relative to the positions of the marker bands. Markers were constructed from amplified rRNA-ITS from several cyanobacterial strains (Janse et al. 2003) and were loaded in the lanes at the sides and in the middle of DGGE gels. Relative densities of Microcystis bands were calculated by dividing the peak intensity of the band by the sum of peak intensities from all Microcystis bands in that lane. Here, the peak intensity is the sum of all pixel values within the band boundaries.

DGGE gel analysis, genotype succession and toxic genotypes. In our analysis of DGGE profiles, we focused on bands originating from Microcystis genotypes. Bands of other Cyanobacteria were discarded because we still lack sufficient data to enable a robust rRNA-ITS classification of such genera. The following assumptions were made to investigate Microcystis genotype succession: (1) DNA extraction efficiency of all Microcystis genotypes was identical because cell wall properties are not likely to vary much within one genus; moreover, we used a thorough chemical-mechanical extraction method. (2) There is no variation in primer site sequence and limited variation in the number of rRNA operons within the Microcystis genus as evidenced by Janse et al. (2003), who tested 20 Microcystis strains. The test rendered 1 band in 17 strains and 2 bands in the remaining 3 strains. (3) Relative band intensities of Microcystis genotypes in the same lane are an adequate estimate for the relative abundances of the different Microcystis strains in that lane.

The latter assumption is supported by a previous study showing DGGE profiles with bands of similar intensity derived from amplification of equivalent numbers of different Microcystis genotypes (Janse et al. 2003; their Fig. 2). However, our study differs from Janse et al. (2003) in 2 important aspects. First, whereas Janse et al. (2003) compared band intensities obtained from the ITSa primer set, we used the ITSc primer set in our study. Second, the samples in our study contained a mixture of Microcystis and other cyanobacterial genera, and amplification of the ITSc rRNA of these other cyanobacterial genera also showed up as bands on the gels. We ran a pilot experiment, using the ITSc primer set, in which we investigated possible changes in band intensities of Microcystis genotypes in the presence of other cyanobacterial genera. Two laboratory strains of Microcystis (NIVA cultures CYA 43 and CYA 140) were mixed in a 1:1 ratio. Subsequently, we added comparable amounts (based on biovolume) of the genera Microcystis (strain PCC 7806), Planktothrix, Anabaena and Aphanizomenon to these mixtures. DNA of all mixtures were extracted and used as a template for PCR amplification according the methods described herein. The band intensities of the resulting DGGE profiles

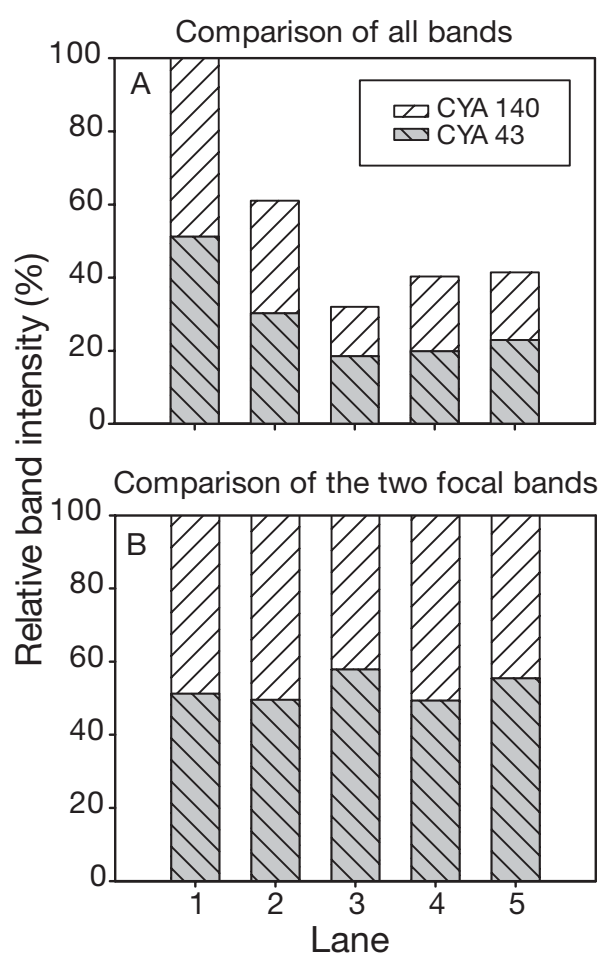

Fig. 1. Band intensities of Microcystis strains CYA 43 and CYA 140 in DGGE profiles obtained from a variety of mixtures with other Cyanobacteria. In each of the mixtures, strains were added in a 1:1 ratio. Band intensities of CYA 43 and CYA 140 are expressed as a percentage of (A) total intensity of all bands in the lane and (B) summed band intensities of the 2 strains in the lane. (A) Band intensities of Microcystis genotypes are suppressed by the presence of other cyanobacterial genera. (B) The 1:1 ratio of the 2 strains is maintained, irrespective of the presence of other Cyanobacteria. Lane 1 = only strain CYA 43 and CYA 140 (1:1); Lane 2 = with Microcystis strain PCC 7806; Lane 3 = with Planktothrix; Lane 4 = with Anabaena and Aphanizomenon; Lane 5 = with Anabaena

were calculated (Fig. 1). This shows that the presence of other cyanobacterial genera suppresses the band intensities of the 2 focal Microcystis genotypes when band intensities are expressed as a percentage of the total intensity of all bands on the entire lane (Fig. 1A). However, irrespective of the presence of other Cyanobacteria, the band intensities of the 2 focal Microcystis genotypes maintained a 1:1 ratio with respect to each other in each of the lanes (Fig. 1B). In another pilot experiment, Microcystis strains CYA 43 and CYA 140 were mixed in different ratios, ranging from 99:1 to 1:99. In each of these mixtures, the ratios could be retrieved from the relative band intensities on the DGGE profile (Kardinaal et al. 2007).

Based on this experimental support, we conclude that relative band intensities of the Microcystis bands within the same lane provide reliable estimates of the relative abundances of Microcystis genotypes in that 
lane; i.e. absolute band intensities of Microcystis lead to incorrect estimates of absolute population abundances, but relative band intensities provide a fair representation of relative abundances in the population composition of Microcystis.

We inferred the microcystin production of genotypes in the natural population from the microcystin production of isolated and cultivated strains or isolated single colonies through similarity of the rRNA-ITS sequences. Sequences obtained in this study were compared to sequences originating from Microcystis colonies and isolated cultures that had been analyzed for microcystin content before. Janse et al. (2004) showed the possibility to discriminate and identify microcystinproducing colonies based on rRNA-ITS sequences from Microcystis colonies. Out of 126 Microcystis rRNA ITS sequences (including strains from Europe and Asia; Otsuka et al. 1999a), 74 of the sequences clustered in 19 clusters. Each cluster contained nearly identical sequences obtained from different colonies or isolates. In 14 out of the 19 clusters, colonies and/or isolates originated from different lakes. The clusters differed in their capacity for microcystin production. However, microcystin production was shared within clusters, i.e. either all or none of the members within a cluster produced microcystins. Using a conservative approach, we assumed in the present study that only those Microcystis ITS sequences that matched 100\% with ITS sequences of previously sequenced Microcystis strains had the same toxigenic properties as those previously sequenced Microcystis strains. For all other Microcystis ITS sequences, we referred to the corresponding genotypes as having an 'unknown microcystin content'.

In Lake Kinselmeer, the phytoplankton community is largely composed of Microcystis and Planktothrix. However, since classification of Planktothrix genotypes using DGGE methods is not yet feasible and the relationship between microcystin production and Planktothrix genotypes is not evident, we did not include the Planktothrix genotypes in our DGGE analyses.

Accession numbers. Sequences were deposited at EMBL. The assigned accession numbers are AM235769 to AM235784 for excised bands and cultured isolates; additional numbers are AM236078 for VC52 and AM236079 for VC34.

\section{RESULTS}

\section{Biovolumes in relation to microcystin concentration}

To investigate to what extent the abundances of potentially toxic cyanobacteria can explain microcystin concentrations, we measured the biovolumes of

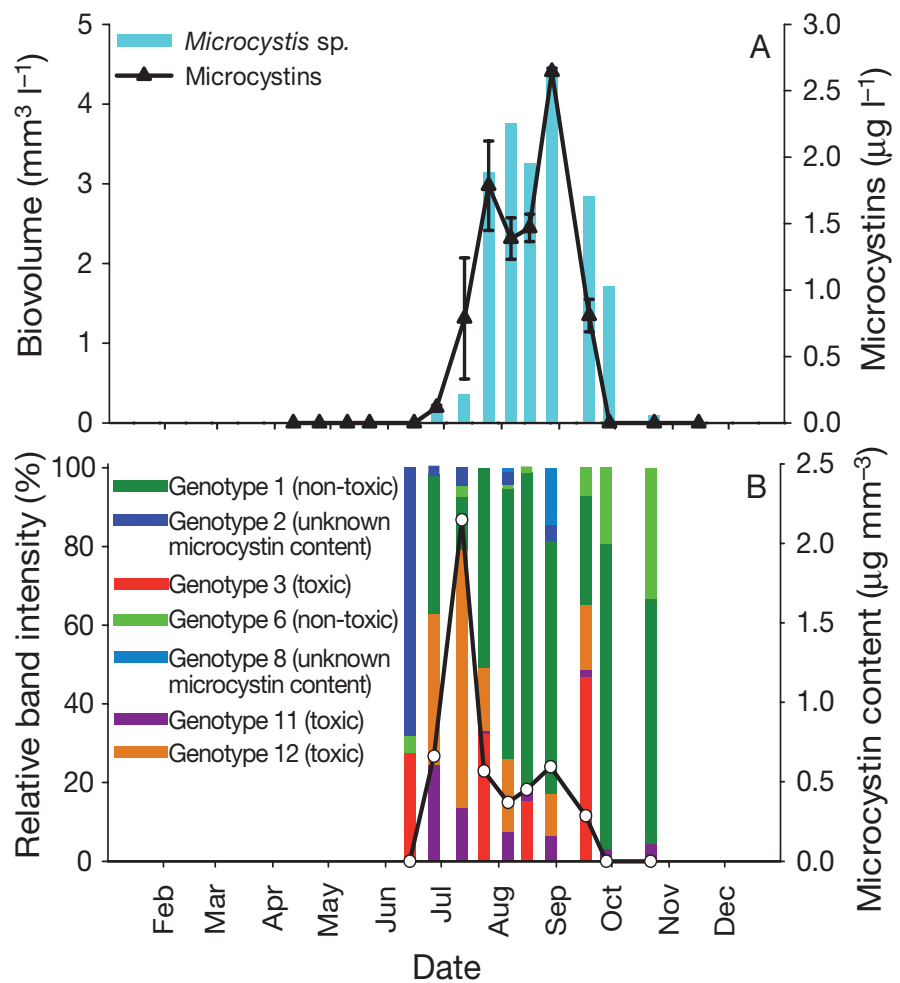

Fig. 2. Seasonal dynamics of Microcystis and microcystin concentrations in Lake 't Joppe. (A) Microcystin concentrations and total biovolume of Microcystis. Error bars show \pm SD of the microcystin concentrations $(\mathrm{N}=3)$. (B) Microcystin contents (solid line) and genotype dynamics of Microcystis based on relative band intensities. Microcystin concentrations are expressed as microcystin-LR equivalents

cyanobacterial genera that are known to include microcystin producers. In Lake 't Joppe and Lake Volkerak, Microcystis was the only microcystin-producing genus, while in Lake Kinselmeer potential microcystin producers included both Microcystis and Planktothrix agardhii. Microcystin concentrations developed roughly parallel to the biovolumes of Microcystis in Lake 't Joppe (Pearson correlation: $\mathrm{R}^{2}$ $=0.71 ; \mathrm{N}=10 ; \mathrm{p}<0.01 ;$ Fig. 2A) and Lake Volkerak $\left(\mathrm{R}^{2}=0.92 ; \mathrm{N}=11 ; \mathrm{p}<0.001 ;\right.$ Fig. 3A), with maxima at the end of August/early September. In Lake Kinselmeer, microcystin concentrations correlated with the sum of Microcystis and Planktothrix biovolumes $\left(\mathrm{R}^{2}=0.83 ; \mathrm{N}=15 ; \mathrm{p}<0.001 ;\right.$ Fig. $\left.4 \mathrm{~A}\right)$. However, the fluctuations in microcystin concentration did not completely coincide with fluctuations in biovolume. This becomes clear when microcystin concentrations are expressed per unit biovolume (i.e. microcystin contents). The microcystin content in Lake 't Joppe was highest at the onset of the Microcystis bloom, at the end of June/early July (Fig. 2B). The microcystin content declined at the end of July, and remained rela- 


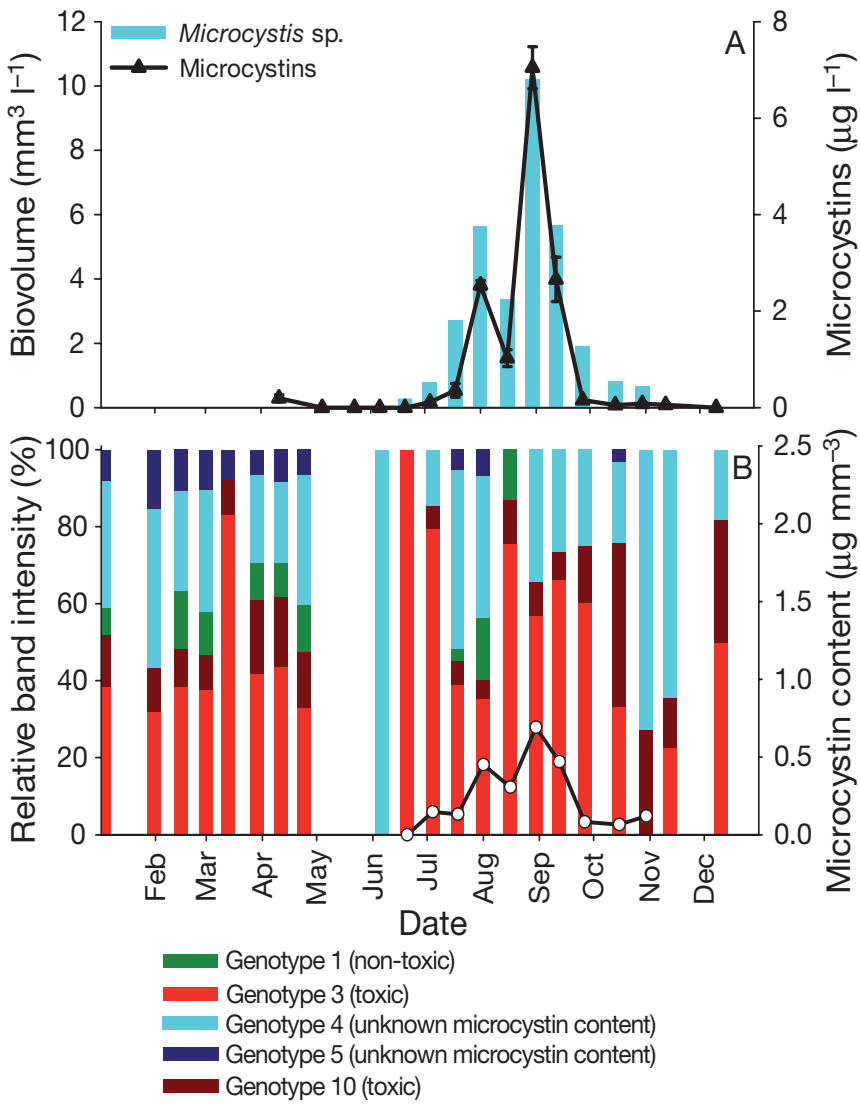

Fig. 3. Seasonal dynamics of Microcystis and microcystin concentrations in Lake Volkerak. (A) Microcystin concentrations and total biovolume of Microcystis. Error bars show $\pm \mathrm{SD}$ of the microcystin concentrations $(\mathrm{N}=3)$. (B) Microcystin contents (solid line) and genotype dynamics of Microcystis based on relative band intensities. Microcystin concentrations are expressed as microcystin-LR equivalents

tively low during August and September. In Lake Volkerak, the microcystin content was less variable and the highest microcystin content coincided with the peak in biovolume at the end of August (Fig. 3B). For Lake Kinselmeer, we could assign most (but not all) microcystin variants to either Microcystis or Planktothrix, and thereby tease apart the contribution of both genera to the total microcystin concentration in this lake. Although the biovolume of Planktothrix exceeded the biovolume of Microcystis, the contribution of Microcystis and Planktothrix to the total microcystin concentration in the lake was quite similar during the cyanobacterial bloom from late August until early October (Fig. 4A). During this bloom, the microcystin production by Planktothrix slightly preceded the microcystin production by Microcystis. The microcystin content of Microcystis was highest at the end of the bloom, in the second half of September (Fig. 4B).

\section{Genotype diversity}

To gain insight into the diversity of cyanobacterial genotypes in Lakes 't Joppe, Volkerak and Kinselmeer, DGGE analyses were performed on a temporal series of samples obtained from these lakes in 2001. Usable cyanobacterial rRNA-ITS DGGE profiles were obtained from Lake Kinselmeer and Lake Volkerak throughout the year, whereas profiles from Lake 't Joppe were obtained only from June onwards. We identified 30 different band positions for Lake 't Joppe, 31 for Lake Volkerak, and 45 for Lake Kinselmeer (Figs. 5, $6 \&$ 7, respectively). A total of 40 bands were excised from the DGGE profiles for sequence analysis. Twenty extracted sequences originated from Cyano-
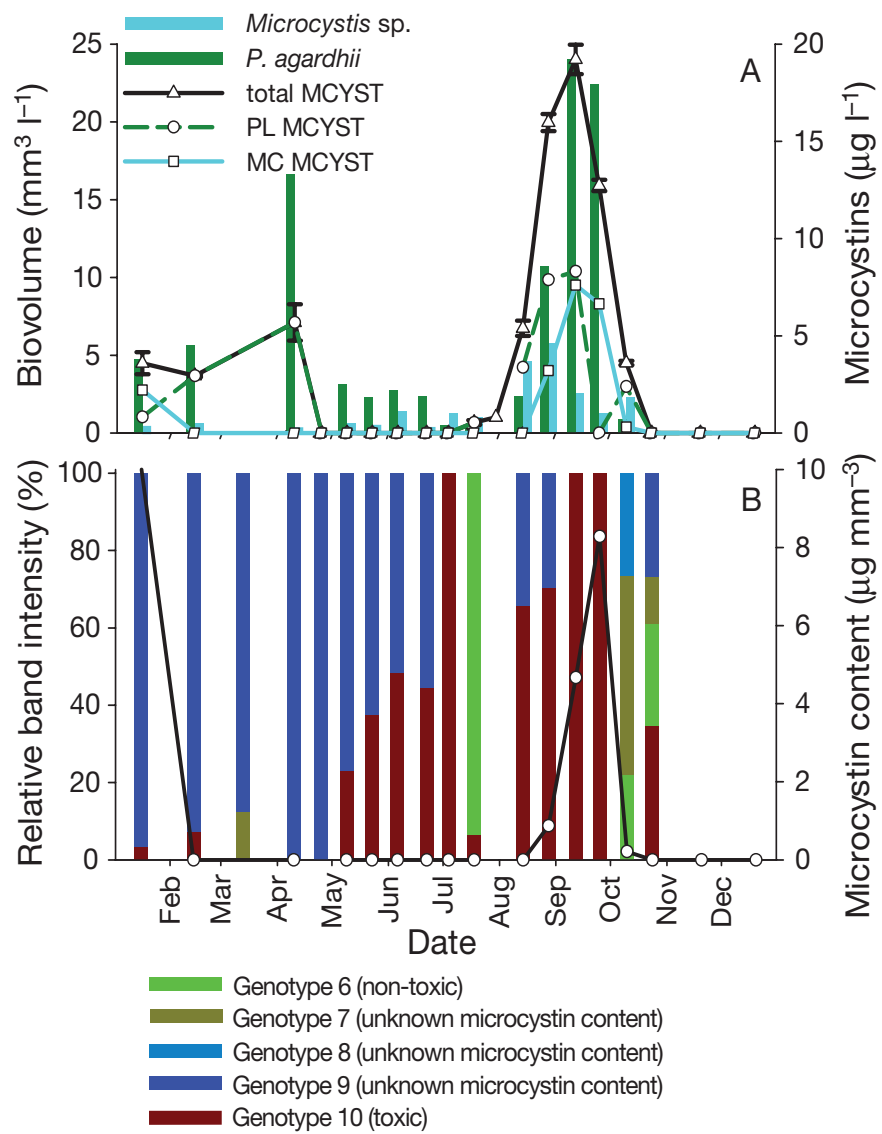

Fig. 4. Seasonal dynamics of the dominant cyanobacterial genera (Microcystis and Planktothrix) in Lake Kinselmeer. (A) Microcystin concentrations and total biovolume of Microcystis and Planktothrix. Total MCYST: total concentration of microcystins; PL MCYST: Planktothrix-specific microcystin concentration; and MC MCYST: Microcystis-specific microcystin concentration (based on microcystin variants found in isolates of Microcystis and Planktothrix from the lake). Error bars show \pm SD of the total microcystin concentration $(\mathrm{N}=3)$. (B) Microcystis-specific microcystin contents (solid line) and genotype dynamics of Microcystis based on relative band intensities. Microcystin concentrations are expressed as microcystin-LR equivalents 
bacteria from the genus Microcystis and were distinguished as 12 different genotypes (Table 1). Other sequences were identified as originating from Planktothrix, Anabaena or Aphanizomenon. In all of the 3 lakes, we found coexistence of toxic and non-toxic genotypes. In Lake Kinselmeer and Lake Volkerak,

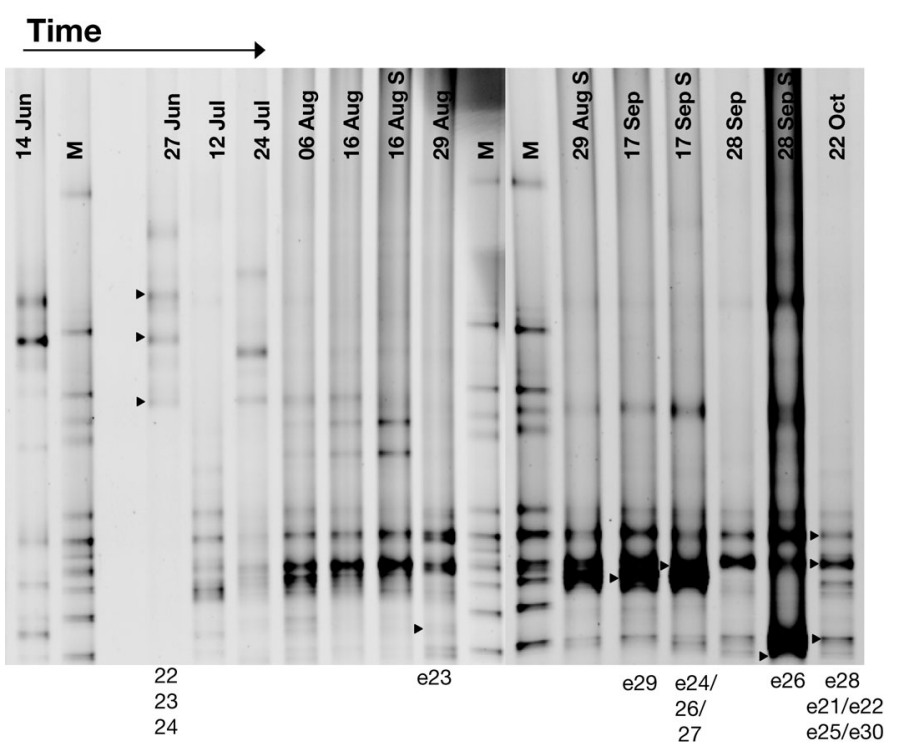

Fig. 5. Seasonal changes in the DGGE pattern of Lake 't Joppe during the year 2001. Bands are PCR products of internal transcribed spacer (ITS) rRNA, amplified with ITS-c primers. - excised bands, which were re-amplified and sequenced. Sequence analyses and NCBI database searches revealed that excised bands (JC) 22 to 24 relate to Aphanizomenon/Anabaena/Synechocystis genotypes. Band e24/26/ 27 consists of 3 excised bands: e24, JC26 and JC27 (see Table 1). The 'e' numbers all relate to Microcystis genotypes according to Table 1. M: marker lane. Lanes marked with both date and $\mathrm{S}$ are samples from surface scums
5 Microcystis genotypes could be distinguished, whereas in Lake 't Joppe 7 Microcystis genotypes could be differentiated (Table 1).

Of the 12 Microcystis genotypes, 7 were found in 1 lake only, 5 were found in 2 lakes, while none of the genotypes were found in all 3 lakes. In total, 6 of our Microcystis genotypes were $100 \%$ identical to ITS sequences from previously analyzed colonies (Janse et al. 2004) or isolated strains. For instance, the sequence from genotype 1 (bands VC52, e21 and e22) matched $100 \%$ with sequences of non-microcystin-producing colonies isolated from Scottish lakes. The sequence of genotype 6 matched 100\% with non-microcystinproducing colonies originating from Dutch and Portuguese lakes. The sequences of genotypes $3,10,11$ and 12 matched $100 \%$ with microcystin-producing colonies and/or isolates originating from several lakes throughout Europe. The remaining 6 genotypes contained new ITS sequences with a maximum similarity of 97 to $99 \%$ to Microcystis sequences deposited in the NCBI database (Table 1).

\section{Microcystis genotype succession}

In Lake 't Joppe, the high microcystin content during early summer (end of June to mid-July) concurred with a high relative band intensity of the toxic genotypes 11 and 12 (Fig. 2B). In August and September, when the microcystin content was low, band intensities were dominated by the non-toxic genotype 1 . In samples with a microcystin content of zero, in October and November, the Microcystis population was dominated by the non-toxic genotypes 1 and 6 .
Fig. 6. Seasonal changes in the DGGE pattern of Lake Volkerak during the year 2001. Bands are PCR products of ITS rRNA, amplified with ITS-c primers. $>$ : excised bands, which were re-amplified and sequenced. Sequence analyses and NCBI database searches revealed that the excised band (VC) 23 relates to chloroplast genes and Anabaena/Aphanizomenon, band 28 relates to Aphanizomenon, band 50 is a heteroduplex band, and band 51 revealed no consensus sequence. Bands 52 (genotype 1), 53 (genotype 3), 54 (genotype 5), 55 (genotype 10) and 34 (genotype 4) are all related to Microcystis genotypes (see Table 1 for details). M: marker lane. Lanes marked with both date and $\mathrm{S}$ are samples from surface scums

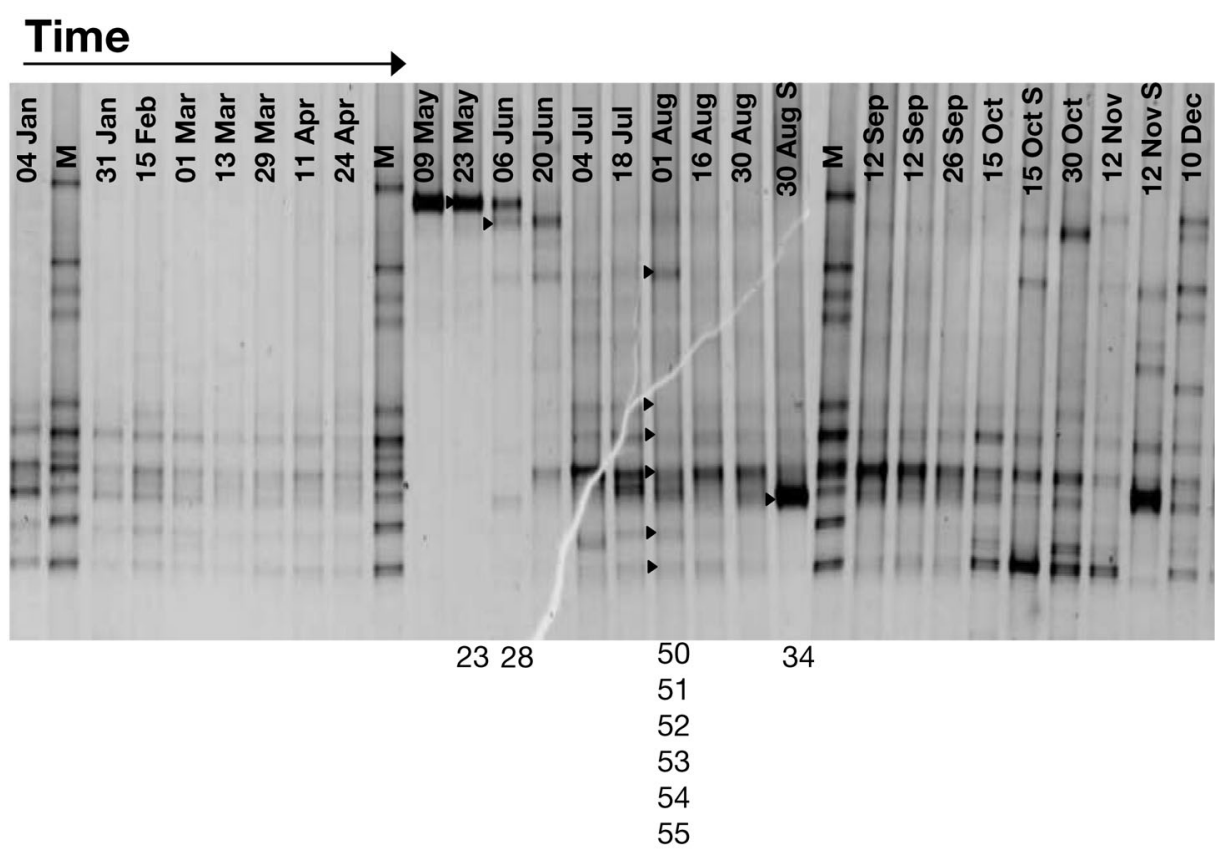




\section{Time}

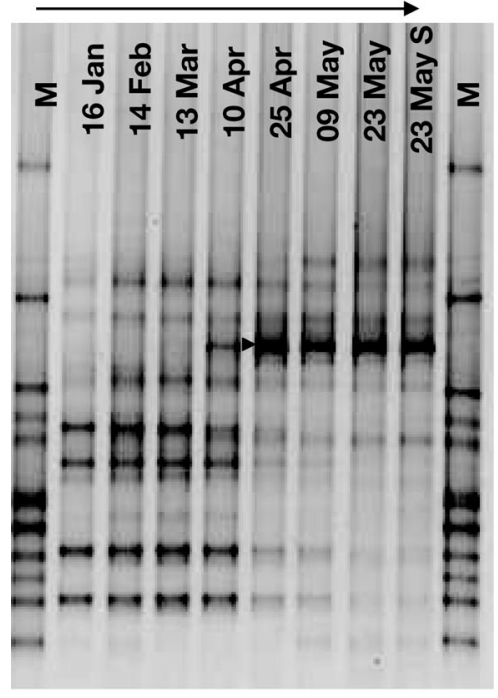

12

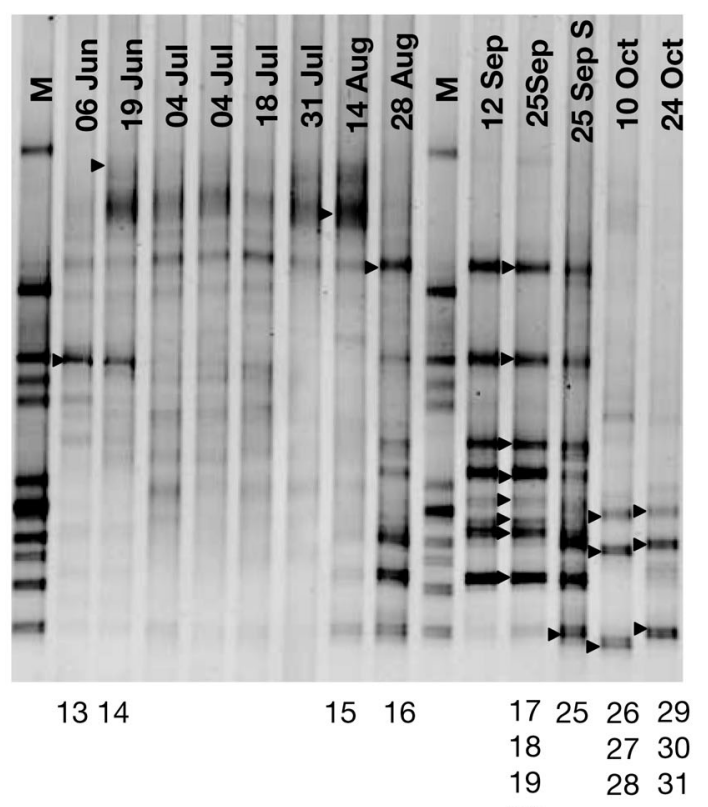

20

21

22

23

24
Fig. 7. Seasonal changes in the DGGE pattern of Lake Kinselmeer during the year 2001. Bands are PCR products of ITS rRNA, amplified with ITS-C primers. : excised bands, which were re-amplified and sequenced. Sequence analyses and NCBI database searches revealed that excised bands (XC) 12 and 13 relate to Aphanizomenon genotypes, bands 14 and 15 relate to Anabaena genotypes, and bands 19, 22 and 23 relate to Planktothrix genotypes. The excised bands 25 (genotype 6), 27 (genotype 7), 28 (genotype 8), 30 (genotype 9) and 31 and 24 (both genotype 10) are related to Microcystis genotypes (see Table 1 for details). The excised bands $16,20,21,26$ and 29 revealed no reliable consensus sequences; bands 17 and 18 are heteroduplex. The 4 dominant bands observed during 16 January to 25 April probably originate from Aphanizomenon. $\mathrm{M}$ : marker lane. Lanes marked with both date and $\mathrm{S}$ are samples from surface scums

Table 1. Microcystis genotypes. Characterization of the genotypes excised and sequenced from DGGE profiles, and their relation to sequences in the NCBI database. (+) microcystin-producing genotype and (-) non-microcystin-producing genotype. The 'e' numbers in Lake 't Joppe refer to bands analyzed by Janse et al. (2004). Country codes: DE = Germany, GB = Great Britain, $\mathrm{MA}=$ Morocco, $\mathrm{NL}=$ Netherlands, $\mathrm{PT}=$ Portugal

\begin{tabular}{|c|c|c|c|c|c|c|c|}
\hline $\begin{array}{l}\text { Geno- } \\
\text { type no. }\end{array}$ & $\begin{array}{l}\text { Band nos. I } \\
\text { 't Joppe }\end{array}$ & $\begin{array}{l}\text { eferring to ex } \\
\text { Kinselmeer }\end{array}$ & $\begin{array}{l}\text { ised bands } \\
\text { Volkerak }\end{array}$ & $\begin{array}{l}\text { Closest matching } \\
\text { colony or isolate }\end{array}$ & $\begin{array}{l}\text { Similarity } \\
(\%)\end{array}$ & Lake of origin & $\begin{array}{l}\text { Accession no. } \\
\text { of bands }\end{array}$ \\
\hline 1 & e21, e22 & & VC52 & K74, K131 (-) & 100 & $\begin{array}{l}\text { Loch Balgavies (GB) and } \\
\text { Loch Rescoby (GB) }\end{array}$ & $\begin{array}{l}\text { AJ619653 } \\
\text { AJ619654 } \\
\text { AM236078 }\end{array}$ \\
\hline 2 & e23 & & & K37 (-) & 97 & ‘t Joppe (NL) & AJ619655 \\
\hline 3 & $\begin{array}{c}\mathrm{JC} 26, \mathrm{JC} 27 \\
\mathrm{e} 24\end{array}$ & & VC53 & Z8，V9 (+) & 100 & $\begin{array}{l}\text { Zeegerplas (NL) and } \\
\text { Volkerak (NL) }\end{array}$ & $\begin{array}{c}\text { AM235769 } \\
\text { AM235770 } \\
\text { AJ619656 } \\
\text { AM235771 }\end{array}$ \\
\hline 4 & & & VC34 & K75-u, K145 (-) & 98 & $\begin{array}{l}\text { Loch Balgavies (GB) and } \\
\text { Lake Wannsee (DE) }\end{array}$ & AM236079 \\
\hline 5 & & & VC54 & K75-1 (-) & 99 & Loch Balgavies (GB) & AM235772 \\
\hline 6 & e25, e30 & $\mathrm{XC} 25$ & & $\begin{array}{l}\text { K37, K68, K105-1, } \\
\text { K31-u (-) }\end{array}$ & 100 & $\begin{array}{l}\text { 't Joppe \& Zeegerplas (NL) } \\
\text { and Parque de Cicade (PT) }\end{array}$ & $\begin{array}{c}\text { AJ619657 } \\
\text { AJ619662 } \\
\text { AM235775 }\end{array}$ \\
\hline 7 & & $\mathrm{XC} 27$ & & $\begin{array}{l}\text { K123, K121, K108, } \\
\text { K117, K110 (-) }\end{array}$ & 97 & $\begin{array}{l}\text { Parque de Cicade (PT) and } \\
\text { Lake Takerkoust (MA) }\end{array}$ & AM235776 \\
\hline 8 & e26 & $\mathrm{XC} 28$ & & K75-u, K145 (-) & 98 & $\begin{array}{l}\text { Loch Balgavies (GB) and } \\
\text { Lake Wannsee (DE) }\end{array}$ & $\begin{array}{l}\text { AJ619658 } \\
\text { AM235777 }\end{array}$ \\
\hline 9 & & XC30 & & K34 (-) & 97 & ‘t Joppe (NL) & AM235778 \\
\hline 10 & & $\begin{array}{l}\mathrm{XC} 31 \\
\mathrm{XC} 24\end{array}$ & VC55 & V163 (+) & 100 & Volkerak (NL) & $\begin{array}{l}\text { AM235779 } \\
\text { AM235774 } \\
\text { AM235773 }\end{array}$ \\
\hline 11 & $\mathrm{e} 28$ & & & K46, K49, K51, etc. ${ }^{\mathrm{a}}(+)$ & 100 & Several lakes in Europe & AJ619660 \\
\hline 12 & e29 & & & Z4, V93 (+) & 100 & $\begin{array}{l}\text { Zeegerplas (NL) and } \\
\text { Volkerak (NL) }\end{array}$ & AJ619661 \\
\hline
\end{tabular}


In Lake Volkerak, the genotype composition was rather stable (Fig. 3B). Throughout the year, the Microcystis population was dominated by toxic genotype 3 and genotype 4 of unknown microcystin content, with co-dominance of toxic genotype 10. The non-toxic genotype 1 and genotype 5 of unknown microcystin content were found less regularly. In May, Microcystis bands could not be detected on the DGGE gels, while Anabaena and Aphanizomenon dominated the cyanobacterial community (data not shown). In this lake, a clear relation between genotype succession and microcystin content could not be detected, since toxic genotypes remained dominant or co-dominant throughout the year. The microcystin dynamics largely tracked the total Microcystis population (Fig. 3A).

In Lake Kinselmeer, the Microcystis population was mainly dominated by genotypes 9 and 10 (Fig. 4B). Genotype 9 of unknown microcystin content dominated during winter and spring, while the toxic genotype 10 became dominant during the summer months from July to October. After the collapse of the Planktothrix population, in October, the non-toxic Microcystis genotype 6 and genotypes 7, 8 and 9 of unknown microcystin content took over the dominant position of toxic genotype 10 .

\section{DISCUSSION}

In the 3 investigated lakes, the seasonal dynamics of microcystin concentrations roughly tracked the abundances (expressed as biovolumes) of the potentially toxic genera Microcystis and Planktothrix. However, the seasonal changes in abundance did not completely explain the fluctuations in microcystin levels. As a possible explanation, we investigated the seasonal succession of toxic and non-toxic genotypes within the genus Microcystis. Using ITS rRNA analysis in combination with DGGE, we indeed found a conspicuous succession of different genotypes in the lakes. This shows that a seasonal succession of different Microcystis genotypes can be a key mechanism determining microcystin concentrations in Microcystis-dominated lakes.

\section{DGGE monitoring of genotype succession}

DGGE profiles are widely used to describe bacterial diversity and population dynamics (e.g. Van der Gucht et al. 2001, Kolmonen et al. 2004, Zeidner \& Béjà 2004, Zwart et al. 2005). In a previous study, cyanobacterial community succession analyzed by rRNA-ITS DGGE profiles revealed contrasting population dynamics in 2 Planktothrix-dominated lakes (Janse et al. 2005). The profiles clearly provided a more detailed view of the changes in cyanobacterial composition when compared to traditional light microscopy methods, especially when phytoplankton densities were low. Dominant genotypes of Planktothrix, identified by sequencing dominant and excised bands, could be matched to cultured isolates originating from the 2 lakes, thereby identifying the key players in microcystin dynamics. In the present study, we applied the same approach to the genus Microcystis. In addition, we included information of band intensities from the DGGE gels to monitor the relative abundances of the different genotypes. For this purpose, we assumed that, because of the similarities in cell wall structure and rRNA primer sites and operon number, the DGGE band intensities reflected the relative abundances of cells from the corresponding Microcystis genotypes. The observed dynamics in DGGE profiles thus revealed a clear picture of the succession of genotypes in the 3 investigated lakes.

The use of universal ITS marker genes in combination with DGGE allows differentiation of effectively all cyanobacterial genera present in freshwater lakes (Janse et al. 2003). Moreover, within the genus Microcystis, this approach enables differentiation at high resolution and distinguishes between toxic and nontoxic Microcystis strains (Janse et al. 2004). However, the variation of ITS sequences in the Microcystis genus is not yet fully described, which may easily result in identification of new genotypes with unknown microcystin contents. Indeed, in this study, we found several new genotypes for which microcystin production has not yet been established (see Figs. 2B, 3B \& 4B). Our DGGE-based approach will thus benefit from an extension of the existing database by isolation of new Microcystis genotypes. These new genotypes should be characterized by their rRNA ITS sequences and microcystin synthetase genes. Moreover, if feasible, their actual microcystin contents should also be assessed. Extension of the database with more genotypes will improve predictions of microcystin dynamics on the basis of genotype composition. Furthermore, the design of specific ITS primers for quantitative PCR of Microcystis genotypes will improve the quantification of genotype succession.

\section{Dynamics of genotype succession and microcystin content}

In total, we found 12 different Microcystis genotypes in the 3 lakes. Some of the genotypes occurred in 2 of the investigated lakes, while other genotypes were detected in just one of the lakes. Since several genotypes matched with sequences originating from colonies isolated from other lakes throughout Europe 
(Table 1), these genotypes are apparently geographically widely distributed.

In each lake, 2 or 3 Microcystis genotypes were dominant and were accompanied by 2 or 3 less common genotypes. We also found coexistence of toxic and non-toxic genotypes in each lake. However, compared to the 59 genotype classes distinguished by Janse et al. (2004), the number of genotypes found in our lakes was rather low; i.e. the diversity of Microcystis genotypes within a lake seems limited to only a handful of coexisting genotypes. This suggests that selection processes are a major determinant of the dominance of different genotypes in different lakes. In each lake, rRNA ITS sequences of at least one of the dominant genotypes matched $100 \%$ with that of previously isolated Microcystis colonies known to produce microcystins (Janse et al. 2004).

A seasonal succession of Microcystis genotypes was observed in each of the sampled lakes. In general, DGGE profiles indicated a stronger contribution of non-toxic genotypes after cyanobacterial biovolumes declined at the end of the season (Figs. 2A, 3A \& 4A). Prior to and during the bloom, marked differences in the dominance of toxic and non-toxic genotypes were found between the lakes. In Lake 't Joppe, the succession between toxic and non-toxic genotypes accounted for clear seasonal patterns in microcystin content of the Microcystis population. The high microcystin content at the onset of the bloom (early July) matched the presence of 2 toxic genotypes. The relatively low microcystin content during the bloom (from the end of July until the end of September) coincided with the dominance of non-toxic genotypes (Fig. 2B). In Lake Volkerak and Lake Kinselmeer, the Microcystis population was dominated by toxic genotypes in July and August (Figs. 3B \& 4B). Hence, in these 2 lakes, the relationship between genotype succession and microcystin dynamics was less conspicuous, as toxic strains dominated throughout the bloom period.

The question arises as to which factors could drive the seasonal succession of toxic and non-toxic Microcystis strains. Several mechanisms might be involved, including selective predation by bivalves (DionisioPires \& Van Donk 2002, Juhel et al. 2006) and zooplankton (Lürling 2003, Rohrlack et al. 2005, Wilson et al. 2006). In addition, Microcystis strains may differ in their buoyancy (Dunton \& Walsby 2005), stickiness (Verspagen et al. 2006b), temperature optima (Otsuka et al. 1999b), and competitive ability for light (Huisman et al. 1999, Kardinaal et al. 2007), which might lead to a seasonal succession of Microcystis genotypes. Future studies investigating ecological differences between Microcystis genotypes may further elucidate the mechanisms of genotype succession, which may help to explain shifts from non-toxic to toxic Microcystis strains.
Acknowledgements. We are most grateful to the 3 reviewers for their helpful comments. We thank the sampling crew of Hoogheemraadschap Rijnland, the laboratory of Hoogheemraadschap Hollands Noorderkwartier, and J. M. H. Verspagen for their help during lake sampling. M. Rep is acknowledged for his assistance in the sequence analysis. This work was funded by the Technology Foundation STW (DYNATOX project no. ACH.4874). J.H. and P.M.V. were supported by the Earth and Life Sciences Foundation (ALW), which is subsidized by the Netherlands Organization for Scientific Research (NWO). Sampling in Lake Volkerak was financially supported by the Ministry of Transport \& Public Works, Directorate Zeeland.

\section{LITERATURE CITED}

Altschul SF, Madden TF, Schäffer AA, Zhang J, Zhang Z, Miller W, Lipman DJ (1997) Gapped BLAST and PSIBLAST: a new generation of protein database search programs. Nucleic Acids Res 25:3389-3402

Carrillo E, Ferrero LM, Alonso-Andicoberry C, Basanta A, Martin A, Lopez-Rodas V, Costas E (2003) Interstrain variability in toxin production in populations of the cyanobacterium Microcystis aeruginosa from water-supply reservoirs of Andalusia and lagoons of Doñana National Park (southern Spain). Phycologia 42:269-274

Chorus I, Bartram J (1999) Toxic cyanobacteria in water: a guide to their public health consequences, monitoring and management. Spon, London

Chorus I, Niesel V, Fastner J, Wiedner C, Nixdorf B, Lindenschmidt KE (2001) Environmental factors and microcystin levels in waterbodies. In: Chorus I (ed) Cyanotoxinsoccurrence, causes, consequences. Springer, Berlin, p 159-177

Codd GA, Lindsay J, Young FM, Morrison LF, Metcalf JS (2005) Harmful cyanobacteria: from mass mortalities to management measures. In: Huisman J, Matthijs HCP, Visser PM (eds) Harmful Cyanobacteria. Springer, Dordrecht, p 1-23

Dionisio-Pires LM, Van Donk E (2002) Comparing grazing by Dreissena polymorpha on phytoplankton in the presence of toxic and non-toxic cyanobacteria. Freshw Biol 47: 1855-1865

Dittmann E, Neilan BA, Erhard M, von Döhren H, Börner T (1997) Insertional mutagenesis of a peptide synthetase gene that is responsible for hepatotoxin production in the cyanobacterium Microcystis aeruginosa PCC 7806. Mol Microbiol 26:779-787

Dunton PG, Walsby AE (2005) The diameter and critical collapse pressure in gas vesicles of Microcystis are correlated with GvpCs of different length. FEMS Microbiol Ecol 247: $37-43$

Fastner J, Flieger I, Neumann U (1998) Optimised extraction of microcystins from field samples: a comparison of different solvents and procedures. Water Res 32:3177-3181

Fastner J, Erhard M, von Döhren H (2001) Determination of oligopeptide diversity within a natural population of Microcystis spp. (Cyanobacteria) by typing single colonies by matrix-assisted laser desorption ionization-time of flight mass spectrometry. Appl Environ Microbiol 67: 5069-5076

Huisman J, Jonker RR, Zonneveld C, Weissing FJ (1999) Competition for light between phytoplankton species: experimental tests of mechanistic theory. Ecology 80: 211-222

Jähnichen S, Petzoldt T, Benndorf J (2001) Evidence for con- 
trol of microcystin dynamics in Bautzen reservoir (Germany) by cyanobacterial population growth rates and dissolved inorganic carbon. Arch Hydrobiol 150:177-196

Janse I, Meima M, Kardinaal WEA, Zwart G (2003) Highresolution differentiation of cyanobacteria by using rRNAinternal transcribed spacer denaturing gradient gel electrophoresis. Appl Environ Microbiol 69:6634-6643

Janse I, Kardinaal WEA, Meima M, Fastner J, Visser PM, Zwart G (2004) Toxic and nontoxic Microcystis colonies in natural populations can be differentiated on the basis of rRNA gene internal transcribed spacer diversity. Appl Environ Microbiol 70:3979-3987

Janse I, Kardinaal WEA, Kamst-van Agterveld M, Meima M, Visser PM, Zwart G (2005) Contrasting microcystin production and cyanobacterial population dynamics in two Planktothrix dominated freshwater lakes. Environ Microbiol 7:1514-1524

Juhel G, Davenport J, O'Halloran J, Culloty S, Ramsay R, James K, Furey A, Allis O (2006) Pseudodiarrhoea in zebra mussels Dreissena polymorpha (Pallas) exposed to microcystins. J Exp Biol 209:810-816

Kardinaal WEA, Visser PM (2005) Dynamics of cyanobacterial toxins: sources of variability in microcystin concentrations. In: Huisman J, Matthijs HCP, Visser PM (eds) Harmful Cyanobacteria. Springer, Dordrecht, p 41-63

Kardinaal WEA, Tonk L, Janse I, Hol S, Slot P, Huisman J, Visser PM (2007) Competition for light between toxic and non-toxic strains of the harmful cyanobacterium Microcystis. Appl Environ Microbiol 73:2939-2946

Kolmonen E, Sivonen K, Rapala J, Haukka K (2004) Diversity of cyanobacteria and heterotrophic bacteria in cyanobacterial blooms in Lake Joutikas, Finland. Aquat Microb Ecol 36:201-211

Kurmayer R, Kutzenberger T (2003) Application of real-time PCR for quantification of microcystin genotypes in a population of the toxic cyanobacterium Microcystis sp. Appl Environ Microbiol 69:6723-6730

Kurmayer R, Dittmann E, Fastner J, Chorus I (2002) Diversity of microcystin genes within a population of the toxic cyanobacterium Microcystis spp. in Lake Wannsee (Berlin, Germany). Microb Ecol 43:107-118

Lawton LA, Edwards C, Codd GA (1994) Extraction and highperformance liquid-chromatographic method for the determination of microcystins in raw and treated waters. Analyst 119:1525-1530

Lürling M (2003) Daphnia growth on microcystin-producing and microcystin-free Microcystis aeruginosa in different mixtures with the green alga Scenedesmus obliquus. Limnol Oceanogr 48:2214-2220

Otsuka S, Suda S, Li RH, Watanabe M, Oyaizu H, Matsumoto S, Watanabe MM (1999a) Phylogenetic relationships between toxic and non-toxic strains of the genus Microcystis based on $16 \mathrm{~S}$ to $23 \mathrm{~S}$ internal transcribed spacer sequence. FEMS Microbiol Lett 172:15-21

Otsuka S, Suda S, Li R, Watanabe M, Oyaizu H, Matsumoto S, Watanabe MM (1999b) Characterization of morphospecies and strains of the genus Microcystis (Cyanobacteria) for a reconsideration of species classification. Phycol Res 47: 189-197

Ouellette AJA, Handy SM, Wilhelm SW (2006) Toxic Microcystis is widespread in Lake Erie: PCR detection of toxin genes and molecular characterization of associated cyanobacterial communities. Microb Ecol 51:154-165

Rinta-Kanto JM, Ouellette AJA, Boyer GL, Twiss MR, Bridgeman TB, Wilhelm SW (2005) Quantification of toxic Microcystis spp. during the 2003 and 2004 blooms in western Lake Erie using quantitative real-time PCR. Environ
Sci Technol 39:4198-4205

Rohrlack T, Henning M, Kohl JG (2001) Isolation and characterization of colony-forming Microcystis aeruginosa strains. In: Chorus I (ed) Cyanotoxins-occurrence, causes, consequences. Springer, Berlin, p 152-158

Rohrlack T, Christoffersen K, Dittmann E, Nogueira L, Vasconcelos V, Börner T (2005) Ingestion of microcystins by Daphnia: intestinal uptake and toxic effects. Limnol Oceanogr 50:440-448

Tillett D, Dittmann E, Erhard M, von Döhren H, Börner T, Neilan BA (2000) Structural organization of microcystin biosynthesis in Microcystis aeruginosa PCC7806: an integrated peptide-polyketide synthetase system. Chem Biol 7:753-764

Vaitomaa J, Rantala A, Halinen K, Rouhiainen L, Tallberg P, Mokelke L, Sivonen K (2003) Quantitative real-time PCR for determination of microcystin synthetase $\mathrm{E}$ copy numbers for Microcystis and Anabaena in lakes. Appl Environ Microbiol 69:7289-7297

Van der Gucht K, Sabbe K, De Meester L, Vloemans N, Zwart G, Gillis M, Vyverman W (2001) Contrasting bacterioplankton community composition and seasonal dynamics in two neighbouring hypertrophic freshwater lakes. Environ Microbiol 3:680-690

Verspagen JMH, Passarge J, Jöhnk KD, Visser PM, Peperzak L, Boers P, Laanbroek HJ, Huisman J (2006a) Water management strategies against toxic Microcystis blooms in the Dutch delta. Ecol Appl 16:313-327

Verspagen JMH, Visser PM, Huisman J (2006b) Aggregation with clay causes sedimentation of the buoyant cyanobacteria Microcystis spp. Aquat Microb Ecol 44:165-174

Via-Ordorika L, Fastner J, Hisbergues M, Dittmann E, Erhard M, Komárek J, Kurmayer R, Chorus I (2004) Distribution of microcystin-producing and non-microcystin producing Microcystis in European freshwater bodies: detection of microcystins and mcy genes in single colonies. Syst Appl Microbiol 27:592-602

Visser PM, Ibelings BW, vander Veer B, Koedood J, Mur LR (1996) Artificial mixing prevents nuisance blooms of the cyanobacterium Microcystis in Lake Nieuwe Meer, the Netherlands. Freshw Biol 36:435-450

Visser PM, Ibelings BW, Mur LR, Walsby AE (2005) The ecophysiology of the harmful cyanobacterium Microcystis: features explaining its success and measures for its control. In: Huisman J, Matthijs HCP, Visser PM (eds) Harmful Cyanobacteria. Springer, Dordrecht, p 109-142

Watanabe MM, Kaya K, Takamura N (1992) Fate of the toxic cyclic heptapeptides, the microcystins, from blooms of Microcystis (Cyanobacteria) in a hypertrophic lake. J Phycol 28:761-767

Welker M, Brunke M, Preussel K, Lippert I, von Döhren H (2004) Diversity and distribution of Microcystis (Cyanobacteria) oligopeptide chemotypes from natural communities studied by single-colony mass spectrometry. Microbiology 150:1785-1796

Wiedner C, Nixdorf B, Heinz R, Wirsing B, Neumann U, Weckesser J (2002) Regulation of cyanobacteria and microcystin dynamics in polymictic shallow lakes. Arch Hydrobiol 155:383-400

Wiedner C, Visser PM, Fastner J, Metcalf JS, Codd GA, Mur LR (2003) Effects of light on the microcystin content of Microcystis strain PCC 7806. Appl Environ Microbiol 69: 1475-1481

Wilson AE, Sarnelle O, Tillmanns AR (2006) Effects of cyanobacterial toxicity and morphology on the population growth of freshwater zooplankton: meta-analyses of laboratory experiments. Limnol Oceanogr 51:1915-1924 
Zeidner G, Béjà O (2004) The use of DGGE analyses to explore eastern Mediterranean and Red Sea marine picophytoplankton assemblages. Environ Microbiol 6: 528-534

Zwart G, Hiorns WD, Methe BA, Van Agterveld MP, Huismans R, Nold SC, Zehr JP, Laanbroek HJ (1998) Nearly identical 16S rRNA sequences recovered from lakes in

Editorial responsibility: Edna Granéli, Kalmar, Sweden
North America and Europe indicate the existence of clades of globally distributed freshwater bacteria. Syst Appl Microbiol 21:546-556

Zwart G, Kamst-van Agterveld MP, van der Werff-Staverman I, Hagen F, Hoogveld HL, Gons HJ (2005) Molecular characterization of cyanobacterial diversity in a shallow eutrophic lake. Environ Microbiol 7:365-377

Submitted: November 7, 2006; Accepted: April 11, 2007 Proofs received from author(s): June 11, 2007 